\title{
A MILLENNIAL PERCEIVED VALUE TOWARDS SEJAUH MATA MEMANDANG A SUSTAINABLE FASHION PRODUCT IN INDONESIA
}

\author{
Muhammad Iqbal Darmawan, Hezel Judah Sumbayak, Susilowati Natakoesoemah \\ LSPR Communications and Business Institute Jakarta, Indonesia \\ Email: iqbaldarmawan.edu@gmail.com, hezeljudah@gmail.com, susilowati.n@1spr.edu
}

\begin{abstract}
As fast fashion contributes to environmental degradation, sustainable fashion has become the counter mechanism for retailers that become contributors to the garment waste promoting slow fashion to the people for a better environment. As for the different intentions the consumers have, purchasing sustainable fashion products means consuming less and only what is needed. Studies explained that in today's society consumers have shown an increasing level of ethical concerns in the context of fashion purchase. This includes millennials. As the most influential generation to date, millennials are actively voicing out their concern on social media and are able to drive conversation for example but not limited to sustainable fashion. Therefore, to understand the reason behind millennials' intention of purchasing sustainable fashion products, research on millennials' perceived value on one of the leading sustainable fashion products in Indonesia "Sejauh Mata Memandang" needs to be done. This research will be conducted with a quantitative methodology through purposive sampling. The quantitative method will be conducted by sending a set of questionnaires towards relevant respondents about their perceived value on a sustainable fashion brand. The research shows that sustainable fashion subtypes have a significant impact on the millennial's perceived value of sustainable fashion products.
\end{abstract}

Keywords: sustainable; perceived; millennials

Received: 2021-12-20; Accepted: 2022-01-05; Published: 2022-01-15

\section{Introduction}

The last 30 years of this century humankind can be judged to be developing positively. Nevertheless, problems such as ecological depletion and climate change emerge as a challenge for humankind (Belz, F.-M., \& Peattie, 2013). Today topics such as climate change, pollution, and healthy living have become a substantial issue for society. One of the integral elements in the issues of the environment is sustainability. Margaret Robertson describes sustainability as a system and an operation that is able to persevere independently for a significant amount of time (Robertson, 2021).

The UN describes sustainability as fulfilling the present and future's needs without hindering its opportunities to gain prosperity. In response to sustainability and to achieve the UN's agenda on Sustainable Development Goals by 2030, many

$\begin{array}{ll}\text { How to cite: } & \text { Darmawan, Sumbayak, \& Natakoesomah (2022) A Millennial Perceived Value Towards Sejauh Mata } \\ & \text { Memandang A Sustainable Fashion Product In Indonesia, 7(1). http://dx.doi.org/10.36418/ Syntax- } \\ & \text { Literate.v7i1.4165 } \\ \text { E-ISSN: } & \text { 2548-1398 } \\ \text { Published by: } & \text { Ridwan Institute }\end{array}$


companies have adopted a more conscious and responsible approach to their business. One of them is the Sustainable Fashion line.

Within the fashion industry, the term 'sustainable fashion' is also used as an antithesis to fast-fashion, which is fast changing, mass-produced, cheap, and often connected to 'throw away' behavior (Barnes, Lea-Greenwood, Zarley Watson, \& Yan, 2013). It has become the counter mechanism for big retailers' names in the fashion industry which contributed to the garment waste such as H\&M or the recently facing bankruptcy Forever 21, where they would change their display within a fortnight.

As of today, there are several sustainable fashion businesses that have emerged and are gaining popularity in Indonesia, one of the examples is Sejauh Mata Memandang. It is an Indonesian fashion brand that does not use any leather or fur products, and they also utilize waste and recycled materials which then are processed into new materials to create the products (Sejauh Mata Memandang, 2016).

Past research on the field of sustainable fashion was majority focused on the consumer attitudes and awareness of sustainable fashion, lacking to explore new apprehension towards this type garment and their association, and expectations with the sustainable fashion. This study aims to analyze the perceived value that Indonesians have towards sustainable fashion products and if they are willing to purchase them or not.

This study will be directed towards millennials who are the followers of sustainable fashion brand Sejauh Mata Memandang. The reasoning behind this is because there are some characteristics distinct to the millennials that makes them more suitable for this study. Firstly, millennials are the one who are most likely to adjust their habits for the sake of the good of the environment (Nielsen, 2014). Secondly, millenials are found to have the highest amount of shopping enjoyment and are the least price conscious in purchasing a fashion product (Moore \& Carpenter, 2008). Finally, Millennials in Indonesia are already shown to be more inclined to spend more for a product that is sustainable.

\section{A. Sustainable Fashion and Perceived Value}

This sustainable fashion concept is aligned with the SDG 13, as the manifestation of the climate action, SDG 14, as an action to save the life below water from dangerous chemical substance as partial production of the garment, and SDG 15 , which aim to save the biodiversity and life on land that could potentially damage by the waste of unused garment.

With the SDGs taken into account and the different intentions the consumers have, for purchasing sustainable fashion products, we differentiate the subtypes of sustainable fashion developed by (Orminski, Tandoc Jr, \& Detenber, 2021) into two frameworks which are fashion production and fashion consumption.

To measure the perceived value that Indonesians place on products that are marketed to adhere to the principles of sustainability, this study conducted the research according to the perceived value (PERVAL) scale. The PERVAL scale has 
19 items and four dimensions which measures how consumers assess products in both functional value, emotional value, and social value.

Functional value has two aspects within it, which is price/value and performance/quality. The former assesses the utility of the product in relation to its price while the latter assesses the quality and performance of the product. Emotional value explores the feelings and emotions that a product could generate for its consumers. Social value is the ability of a product to enhance the consumers' social concept. The four dimensions that will be measured with the PERVAL scale are quality, emotional, price, and social (Sweeney \& Soutar, 2001).

\section{B. Indonesian Perceived Value on Sustainable Fashion}

Studies explained that in today's society consumers have shown an increasing level of ethical concerns in the context of fashion purchase (Niinimäki, 2010). In Indonesia a study conducted by Nielsen finds that more than six in ten people in Indonesia (64\%) are willing to pay a premium, to purchase products from a company that has committed to contribute positively towards the environment or the social issues (Nielsen, 2014).

Another research also suggested that consumers are mostly concerned about the social and environmental consequences of their buying behavior, especially when the production is violating the human right of its workers, or creating an environmental degradation. Responsible production, be it in the form of using organic material, and eco-friendly treatment in particular has been identified as one of the most important ethical concerns when making purchase decisions (Shaw \& Tomolillo, 2004); (Freestone \& McGoldrick, 2008).

It is also found that Millennials in Indonesia are also willing to pay for premium products that are believed to have a positive impact on the environment (Natakoesoemah \& Adiarsi, 2020). Despite the progressive level of awareness for a new form of fashion trend and consumption, especially the eco-friendly fashion items, there is still a behavior gap among the consumer (Henninger, Bürklin, \& Niinimäki, 2019); (McNeill \& Venter, 2019); (Park \& Lin, 2020). This is due to the thin line between using sustainable fashion items as an emotional attachment to fashion and their way of expressing it but, at the same time the narrative of sustainable fashion businesses to always put communal interest over individual interest and identities (McNeill \& Venter, 2019).

\section{Method}

This research seeks to understand how much value Indonesian Millennials place towards a sustainable fashion product, and to observe whether the placement of sustainable development principles in the marketing efforts of a fashion brand will affect the purchase decision of a consumer. Furthermore, this study will learn what are the Indonesian consumers associations to a sustainable fashion product.

The method used in this research is quantitative research, namely by the survey. The survey was conducted by distributing questionnaires to predetermined research 
samples. The population of this study were millennials comprising boys and girls aged 18-25 years. The survey was spread through social media platforms, instagram directly targeted the followers of Sejauh Mata Memandang.

Primary data collection used a questionnaire distributed online during the months of July-August 2021. The sample selection was carried out using a non-probability sampling method, and the sampling was determined using purposive sampling. The number of samples in the study was 100 respondents.

H0: $\rho 1=0$, explains that there is no correlation between perceived value and the millennials attitude towards sustainable fashion products Sejauh Mata Memandang.

H1: $\rho 1 \neq 0$, there is correlation between perceived value and the millennials attitude towards sustainable fashion products Sejauh Mata Memandang.

H0: $\rho 2=0$, perceived value has no influence on the millennials attitude towards sustainable fashion products Sejauh Mata Memandang.

\section{Results and Discussions}

Respondents' profile based on the amount of income explains that from 100 respondents studied, 44 people (44\%) are from middle-low profile individuals with 1-5 million incomes per month, 27 of them (27\%) are from middle up, comprising 5-10 million income per month. 12 people (12\%) are from the income category of 10-15 million income per month, 9 people (9\%) from the income category of 15 million above, and lastly 8 people ( $8 \%$ ) from the respondents are from the income category of below 1 million per month. Respondents' profile based on their fashion spending explains that the respondents have diverse characteristics when it comes to yearly fashion spending. 29 people or (29\%) of the respondents spent at least IDR 500.000 1.000.000 million per year, 26 people $(26 \%)$ of the respondents spent IDR 2.000.000 5.000 .000 million per year, 18 people (18\%) spent IDR $1.000 .000-2.000 .000$ per year, 14 people (14\%) of the respondents spent below IDR 500.000, 10 people (10\%) of the respondents spent IDR 5.000.000 - 15.000.000 per year, and lastly 3 people (3\%) of them spent above IDR 15.000.000 per year.

Respondents' profile based on where they purchase their fashion products reveals that the majority of respondents purchase their fashion products from either online shops or malls. 49 people (49\%) of respondents buy their fashion products at online shops (toko online) while 45 others $(45 \%)$ of respondents purchase their fashion products at shopping centers or malls. Meanwhile, 6 people $(6 \%)$ of respondents purchase their fashion products at factory outlets, traditional stores (pasar tradisional), and have their clothes custom from the tailors (penjahit). 
Table 1

Correlation between Sustainable Fashion Subtypes to Perceived Value

\begin{tabular}{|c|c|c|c|c|c|c|}
\hline Aspects & Items & $\begin{array}{l}\text { Strongly } \\
\text { Disagree }\end{array}$ & Disagree & Doubtful & Agree & $\begin{array}{l}\text { Strongly } \\
\text { Agree }\end{array}$ \\
\hline \multirow[t]{4}{*}{$\begin{array}{l}\text { Environmental- } \\
\text { Friendly } \\
\text { Fashion }\end{array}$} & $\begin{array}{l}\text { Familiarity with } \\
\text { environmental-friendly } \\
\text { fashion. }\end{array}$ & - & 22 & - & 40 & 38 \\
\hline & $\begin{array}{l}\text { Need for fashion products to } \\
\text { have a positive impact on the } \\
\text { environment. }\end{array}$ & - & 5 & - & 31 & 64 \\
\hline & $\begin{array}{l}\text { Willing to purchase } \\
\text { environmental-friendly } \\
\text { fashion products. }\end{array}$ & - & 6 & - & 52 & 42 \\
\hline & $\begin{array}{l}\text { Wears environmental-friendly } \\
\text { fashion products more often } \\
\text { than regular fashion products. }\end{array}$ & 3 & 47 & - & 38 & 12 \\
\hline \multirow[t]{3}{*}{$\begin{array}{l}\text { Organic } \\
\text { Fashion }\end{array}$} & $\begin{array}{l}\text { Believes that fashion products } \\
\text { from organic materials are } \\
\text { beneficial to the environment. }\end{array}$ & 1 & 5 & - & 62 & 32 \\
\hline & $\begin{array}{l}\text { Likes organic fashion } \\
\text { products. }\end{array}$ & - & 21 & - & 55 & 24 \\
\hline & $\begin{array}{l}\text { Prefers to purchase or wear } \\
\text { organic fashion products. }\end{array}$ & - & 28 & - & 55 & 17 \\
\hline \multirow[t]{3}{*}{$\begin{array}{l}\text { Recycled } \\
\text { Fashion }\end{array}$} & $\begin{array}{l}\text { Believes that recycled fashion } \\
\text { products have a positive } \\
\text { impact on the environment. }\end{array}$ & - & 13 & - & 49 & 38 \\
\hline & $\begin{array}{l}\text { Willing to purchase recycled } \\
\text { fashion products. }\end{array}$ & - & 25 & - & 58 & 17 \\
\hline & $\begin{array}{l}\text { Prefers to recycle used fashion } \\
\text { products rather than discard it. }\end{array}$ & - & 30 & - & 51 & 19 \\
\hline \multirow[t]{3}{*}{$\begin{array}{l}\text { Upcycled } \\
\text { fashion }\end{array}$} & $\begin{array}{l}\text { Believes that upcycling used } \\
\text { fashion products is better than } \\
\text { purchasing a new one because } \\
\text { of its impact on the } \\
\text { environment. }\end{array}$ & 1 & 18 & - & 47 & 34 \\
\hline & $\begin{array}{l}\text { Willing to upcycle used } \\
\text { fashion products. }\end{array}$ & 1 & 28 & - & 46 & 25 \\
\hline & $\begin{array}{l}\text { Likes to purchase upcycled } \\
\text { fashion products. }\end{array}$ & 2 & 39 & - & 50 & 9 \\
\hline \multirow[t]{2}{*}{$\begin{array}{l}\text { Second-hand } \\
\text { fashion }\end{array}$} & $\begin{array}{l}\text { Believes that second-hand } \\
\text { fashion businesses have a } \\
\text { positive impact on the } \\
\text { environment. }\end{array}$ & - & 16 & - & 59 & 25 \\
\hline & Likes to purchase and wear & - & 48 & - & 39 & 13 \\
\hline
\end{tabular}




\begin{tabular}{|c|c|c|c|c|c|c|}
\hline & \multicolumn{6}{|l|}{ second-hand fashion products. } \\
\hline & $\begin{array}{l}\text { Likes to sell used fashion } \\
\text { items. }\end{array}$ & 4 & 55 & - & 28 & 13 \\
\hline \multirow[t]{3}{*}{$\begin{array}{l}\text { Collaborative } \\
\text { Consumption }\end{array}$} & $\begin{array}{l}\text { Believes that collaborative } \\
\text { fashion businesses have a } \\
\text { positive impact on the } \\
\text { environment. }\end{array}$ & - & 23 & - & 58 & 19 \\
\hline & $\begin{array}{l}\text { Willing to rent fashion } \\
\text { products for use in special } \\
\text { events. }\end{array}$ & 2 & 27 & - & 52 & 19 \\
\hline & $\begin{array}{l}\text { Willing to rent fashion items } \\
\text { to others. }\end{array}$ & 7 & 55 & - & 26 & 12 \\
\hline \multirow[t]{2}{*}{ Price } & $\begin{array}{l}\text { Believes that sustainable } \\
\text { fashion products are } \\
\text { affordable. }\end{array}$ & 2 & 29 & - & 49 & 20 \\
\hline & $\begin{array}{l}\text { Willing to pay more for a } \\
\text { sustainable fashion product. }\end{array}$ & 1 & 26 & - & 57 & 16 \\
\hline \multirow[t]{2}{*}{ Quality } & $\begin{array}{l}\text { Believes that sustainable } \\
\text { fashion products have a higher } \\
\text { quality. }\end{array}$ & 1 & 31 & - & 50 & 18 \\
\hline & $\begin{array}{l}\text { Believes that sustainable } \\
\text { fashion products are more } \\
\text { well-made. }\end{array}$ & 1 & 23 & - & 57 & 19 \\
\hline \multirow[t]{3}{*}{ Emotional } & $\begin{array}{l}\text { Believes that purchasing or } \\
\text { wearing fashion products will } \\
\text { make them a better person. }\end{array}$ & - & 30 & - & 54 & 16 \\
\hline & $\begin{array}{l}\text { Feels satisfied to purchase or } \\
\text { wear fashion products. }\end{array}$ & - & 19 & - & 65 & 16 \\
\hline & $\begin{array}{l}\text { Believes that by wearing } \\
\text { fashion products others will } \\
\text { see them as a better person. }\end{array}$ & - & 42 & - & 47 & 11 \\
\hline \multirow[t]{2}{*}{ Social } & $\begin{array}{l}\text { Believes that purchasing or } \\
\text { wearing fashion products will } \\
\text { increase their acceptance in } \\
\text { society. }\end{array}$ & - & 55 & - & 34 & 11 \\
\hline & $\begin{array}{l}\text { Purchases fashion products to } \\
\text { increase prestige. }\end{array}$ & 4 & 56 & - & 27 & 13 \\
\hline
\end{tabular}

\section{Source: Own research}

Based on the table above, it can be seen that the responses are mostly positive across the board, with the exception of the social aspect of the perceived value of sustainable fashion products which have negative responses. From this data, it can be inferred that sustainable fashion products have minimal impact on the social aspect. 
Table 2

Descriptive Analysis

\begin{tabular}{|c|c|c|c|c|c|}
\hline & $\mathrm{N}$ & Min & Max & Mean & Std. Deviation \\
\hline X.1 & 100 & 2 & 5 & 3.94 & 1.127 \\
\hline X.2 2 & 100 & 2 & 5 & 4.54 & .744 \\
\hline X.3 & 100 & 2 & 5 & 4.30 & .759 \\
\hline X.4 & 100 & 1 & 5 & 3.09 & 1.207 \\
\hline X.5 & 100 & 1 & 5 & 4.19 & .761 \\
\hline X.6 & 100 & 2 & 5 & 3.82 & 1.029 \\
\hline X.7 & 100 & 2 & 5 & 3.61 & 1.072 \\
\hline X.8 & 100 & 2 & 5 & 4.12 & .946 \\
\hline X.9 & 100 & 2 & 5 & 3.67 & 1.035 \\
\hline X.10 & 100 & 2 & 5 & 3.59 & 1.111 \\
\hline X.11 & 100 & 1 & 5 & 3.95 & 1.077 \\
\hline X.12 & 100 & 1 & 5 & 3.66 & 1.165 \\
\hline X.13 & 100 & 1 & 5 & 3.25 & 1.132 \\
\hline X.14 & 100 & 2 & 5 & 3.93 & .946 \\
\hline X.15 & 100 & 2 & 5 & 3.17 & 1.173 \\
\hline X.16 & 100 & 1 & 5 & 2.91 & 1.232 \\
\hline X.17 & 100 & 2 & 5 & 3.73 & 1.024 \\
\hline X.18 & 100 & 1 & 5 & 3.59 & 1.138 \\
\hline X.19 & 100 & 1 & 5 & 2.81 & 1.245 \\
\hline Valid N (listwise) & 100 & & & & \\
\hline
\end{tabular}

Source: SPSS data processing

According to the table it is found that on average the lowest indicating answer is on indicator "Willing to rent fashion items to others" with a value of 2.81 , while the highest indicating answer is on indicator "Feels satisfied to purchase or wear fashion products" with a value of 4.54 . 
Table 3

Descriptive Statistics

\begin{tabular}{lcrrrr}
\hline & N & Min & Max & Mean & Std. Deviation \\
\hline Y.1 & 100 & 2 & 5 & 3.30 & 1.210 \\
\hline Y.2 & 100 & 1 & 5 & 3.56 & 1.166 \\
\hline Y.3 & 100 & 1 & 5 & 3.61 & 1.072 \\
\hline Y.4 & 100 & 1 & 5 & 3.53 & 1.141 \\
\hline Y.5 & 100 & 1 & 5 & 3.70 & 1.059 \\
\hline Y.6 & 100 & 2 & 5 & 3.56 & 1.085 \\
\hline Y.7 & 100 & 2 & 5 & 3.78 & .938 \\
\hline Y.8 & 100 & 2 & 5 & 3.27 & 1.127 \\
\hline Y.9 & 100 & 2 & 5 & 3.01 & 1.159 \\
\hline Y.10 & 100 & 1 & 5 & 2.89 & 1.230 \\
\hline Valid N (listwise) & 100 & & & & \\
\hline
\end{tabular}

Source: SPSS data processing

According to the table it is found that on average the lowest indicating answer is on indicator "Purchases fashion products to increase prestige" with a value of 2.89 , while the highest indicating answer is on indicator "Need for fashion products to have a positive impact on the environment" with a value of 3.78 .

Table 4

Simple Regression Analysis

\begin{tabular}{|c|c|c|c|c|c|c|}
\hline \multirow[b]{2}{*}{ Model } & & \multicolumn{2}{|c|}{ Unstandardized Coefficients } & \multirow{2}{*}{$\begin{array}{c}\begin{array}{c}\text { Standardized } \\
\text { Coefficients }\end{array} \\
\text { Beta }\end{array}$} & \multirow[b]{2}{*}{$\mathrm{t}$} & \multirow[b]{2}{*}{ Sig. } \\
\hline & & B & Std. Error & & & \\
\hline 1 & (Constant) & -.290 & 3.714 & & -078 & .936 \\
\hline & $\mathrm{x}$ & .494 & .052 & .689 & 9.408 & .000 \\
\hline
\end{tabular}

Source: SPSS data processing

According to the table, the resulting corresponding multiple linear regression are as follows:

\section{A. Perceived Value $(Y)=\mathbf{- 0 , 2 9 0}+\mathbf{0 , 4 9 4}$ Sustainable Fashion Subtype $(X)+e$}

The correspondence above are explained as follows:

1. According to the regression above, a constant of 0,290 is achieved. This means that if the Sustainable Fashion Subtype (X) variable is assumed to be constant, then the Perceived Value (Y) variable will generate a value of -0,290

2. The value 0,494 on the variable of Sustainable Fashion Subtype (X) has a positive value so it can be said that the variable of Sustainable Fashion Subtype (X) has a positive relationship with the Perceived Value (Y) variable. If there is 
an increase of the Sustainable Fashion Subtype (X) variable by one, it will increase the Perceived Value (Y) variable by 0,494.

\section{B. Coefficient Determination}

The value that is utilized in this research is the Adjusted R Square value, and the value can be seen in the following table.

Table 5

Model Summary

\begin{tabular}{|l|c|r|r|r|r|}
\hline Model & $\mathrm{R}$ & $\begin{array}{c}\mathrm{R} \\
\text { Square }\end{array}$ & $\begin{array}{c}\text { Adjusted } \\
\mathrm{R} \\
\text { Square }\end{array}$ & $\begin{array}{c}\text { Std. } \\
\text { Error of } \\
\text { the } \\
\text { Estimate }\end{array}$ & $\begin{array}{c}\text { Durbin- } \\
\text { Watson }\end{array}$ \\
\hline 1 & $.689^{\mathrm{a}}$ & .475 & .469 & 5.906 & 1.723 \\
\hline
\end{tabular}

Source: SPSS data processing

a. Predictors: (Constant), $\mathrm{X}$

b. Dependent Variable: $\mathrm{Y}$

According to the table it can be assessed that the Adjusted R Square value is 0,469 or $46.9 \%$. This can indicate that the independent variable Sustainable Fashion Subtype (X) can affect the dependent variable of Perceived Value (Y) as much as $46.9 \%$, and the remaining $53.1 \%$ is affected by a different factor that is not researched.

\section{Linear Regression Hypothesis Test}

The $\mathrm{t}$ test on this research is utilized to test the validity of the correlation between the independent variable of Sustainable Fashion Subtype (X) and the dependent variable Perceived Value (Y). The t test on this research can be seen in the following table:

Table 6

\section{Coefficients (a) of dependent variable Perceived Value}

\begin{tabular}{|c|c|c|c|c|c|c|}
\hline \multirow[b]{2}{*}{ Model } & & \multicolumn{2}{|c|}{$\begin{array}{l}\text { Unstandardized } \\
\text { Coefficients }\end{array}$} & \multirow{2}{*}{\begin{tabular}{|c|c}
$\begin{array}{c}\text { Standardize } \\
\mathrm{d}\end{array}$ \\
Coefficients
\end{tabular}} & \multirow[b]{2}{*}{$\mathrm{t}$} & \multirow[b]{2}{*}{ Sig. } \\
\hline & & B & Std. Error & & & \\
\hline \multirow[t]{2}{*}{1} & (Constant) & -290 & 3.714 & & -.078 & .938 \\
\hline & $x$ & .494 & .052 & .689 & 9.408 & .000 \\
\hline
\end{tabular}

Source: SPSS data processing

According to the table the hypothesis of the $\mathrm{t}$ test on the Sustainable Fashion Subtype $(\mathrm{X})$ variable are as follows:

- H0: $\rho 1=0$, Sustainable Fashion Subtype (X) variable does not have a significant partial determination on the Perceived Value (Y) variable.

- $\quad \mathrm{H} 1: \rho 1 \neq 0$, Sustainable Fashion Subtype (X) variable does have a significant partial determination on the Perceived Value $(\mathrm{Y})$ variable. 
On the Sustainable Fashion Subtype (X) variable with significance level of $90 \%(\alpha=0,1)$. The significance level ( $\mathrm{P}$ Value) is $0.000<0,1$. According to that, then $\mathrm{H}_{0}$ is rejected which inferred that the Sustainable Fashion Subtype (X) variable has On the Sustainable Fashion Subtype (X) variable with a significant influence on the Perceived Value (Y) variable.

Table 7

Anova Test

\begin{tabular}{|ll|r|r|r|r|r|}
\hline Model & & $\begin{array}{c}\text { Sum of } \\
\text { Squares }\end{array}$ & \multicolumn{1}{c|}{ df } & $\begin{array}{c}\text { Mean } \\
\text { Square }\end{array}$ & F & Sig. \\
\hline 1 & Regression & 3087.894 & 1 & 3087.89 & 88.517 & .000 \\
& & & 4 & & \\
& Residual & 3418.696 & 98 & 34.885 & & \\
& Total & 6506.590 & 99 & & & \\
& & & & & & \\
\hline
\end{tabular}

Source: SPSS data processing

According to the table from the F-test in this research we get an $\mathrm{F}$ count of 88.517 and a significance value ( $\mathrm{P}$ value) of 0.000 . With a significance level of $90 \%$ $(\alpha=0,01)$. The significance value ( $\mathrm{P}$ value) of $0.000<0.01)$. According to the comparison, then $\mathrm{H} 0$ is rejected and the Sustainable Fashion Subtype (X) variable has a significant simultaneous effect on the Perceived Value (Y) variable.

\section{Conclusion}

The participants indicated that they were motivated to purchase sustainable fashion products for the following perceived values: prize and affordability, quality, emotional value, and social value. Overall, quality was found to be positively and significantly important because it considers the product performance and how well the product is made. As sustainable fashion products promote slow fashion, the respondents believe that quality is an essential aspect of ensuring that they don't need to change or buy new clothes in the long run. It is followed by price, and consumers are willing to pay more for an added value to this type of product. The respondents also considered emotional value important as it made them feel better and satisfied for contributing to the environmental causes. The social value was found to have a low influence on purchase intention toward sustainable fashion products due to less purpose of making themselves accepted and fit in the society. 


\section{BIBLIOGRAPHY}

Barnes, Liz, Lea-Greenwood, Gaynor, Zarley Watson, Maegan, \& Yan, Ruoh Nan. (2013). An exploratory study of the decision processes of fast versus slow fashion consumers. Journal of Fashion Marketing and Management: An International Journal, 17(2), 141-159. Google Scholar

Belz, F.-M., \& Peattie, K. (2013). Sustainable Marketing A Global Perspective. West Sussex: Wiley. Google Scholar

Freestone, Oliver M., \& McGoldrick, Peter J. (2008). Motivations of the ethical consumer. Journal of Business Ethics, 79(4), 445-467. Google Scholar

Henninger, Claudia Elisabeth, Bürklin, Nina, \& Niinimäki, Kirsi. (2019). The clothes swapping phenomenon-when consumers become suppliers. Journal of Fashion Marketing and Management: An International Journal. Google Scholar

McNeill, Lisa, \& Venter, Brittany. (2019). Identity, self-concept and young women's engagement with collaborative, sustainable fashion consumption models. International Journal of Consumer Studies, 43(4), 368-378. Google Scholar

Moore, Marguerite, \& Carpenter, Jason M. (2008). Intergenerational perceptions of market cues among US apparel consumers. Journal of Fashion Marketing and Management: An International Journal, 12(3), 323-337. Google Scholar

Natakoesoemah, Susilowati, \& Adiarsi, Gracia Rachmi. (2020). The Indonesian Millenials Consumer Behaviour on Buying Eco-Friendly Products: The Relationship Between Environmental Knowledge and Perceived Consumer Effectiveness. International Journal of Multicultural and Multireligious Understanding, 7(9), 292-302. Google Scholar

Nielsen, N. V. (2014). Global consumers are willing to put their money where their heart is when it comes to goods and services from companies committed to social responsibility. June, New York. Google Scholar

Niinimäki, Kirsi. (2010). Eco-clothing, consumer identity and ideology. Sustainable Development, 18(3), 150-162. Google Scholar

Orminski, Jeanette, Tandoc Jr, Edson C., \& Detenber, Benjamin H. (2021). \# sustainablefashion-A Conceptual Framework for Sustainable Fashion Discourse on Twitter. Environmental Communication, 15(1), 115-132. Google Scholar

Park, Hyun Jung, \& Lin, Li Min. (2020). The effects of match-ups on the consumer attitudes toward internet celebrities and their live streaming contents in the context of product endorsement. Journal of Retailing and Consumer Services, 52, 101934. Google Scholar

Robertson, Margaret. (2021). Sustainability principles and practice. New York: 
Routledge. Google Scholar

Sejauh Mata Memandang. (2016). About Sejauh Mata Memandang. Retrieved 125 , 2020, from Sejauh Mata Memandang. Retrieved from http://sejauh.com/about/

Shaw, Deirdre, \& Tomolillo, D. (2004). Undressing the ethical issues in fashion: a consumer perspective. International Retail Marketing: A Case Study Approach, 141-152. Google Scholar

Sweeney, Jillian C., \& Soutar, Geoffrey N. (2001). Consumer perceived value: The development of a multiple item scale. Journal of Retailing, 77(2), 203-220. Google Scholar

\section{Copyright holder:}

Muhammad Iqbal Darmawan, Hezel Judah Sumbayak, Susilowati Natakoesoemah (2022)

First publication right:

Syntax Literate: Jurnal Ilmiah Indonesia

This article is licensed under:

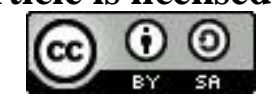

